\title{
KONSEP PEMBELAJARAN PIANO: SEBUAH SUMBANGSIH PEMIKIRIAN
}

\author{
Genta Kurnia Andriyanto \\ STT Kristus Alfa Omega \\ Jl. Jati Barang, Mijen, Kota Semarang, Jawa Tengah 50219 \\ gentandre.music97@gmail.com
}

\begin{abstract}
Practicing a piano is important for a pianist. A good training program certainly needs to be designed for every pianist. Long time and self-discipline as the basis for training, is actually not enough to get maximum results. Complaints such as saturation, boredom, finger injury, even frustration are always a cliché problem that often occurs. Creating a training program that is right on target and efficient is very necessary to be designed, so that training can be fun, stimulate and of course get a fast and significant development. Then what kind of exercise program should the pianist know in order to get maximum results? The following will explain some of the suggestions and trick that can help a pianist, so he can make the best use of training time.
\end{abstract}

Keywords: piano learning; music practice; music learning

\section{Pendahuluan}

Musik merupakan salah satu seni yang menarik banyak perhatian manusia, terlebih alat musik atau musik piano. Piano juga dikenal sebagai raja dari alat musik, karena mudah dimengerti, memiliki wilayah nada yang luas, dapat mewakili semua instrumen musik. Piano juga memiliki suara yang khas, teknik yang menarik, dan memiliki "kelas" tersendiri bagi manusia. Hal inilah yang membuat orang mudah tertarik pada alat musik ini, mulai dari sekedar menjadi penikmat, sebagai sebuah hobi, hingga bagi yang ingin mendalami secara profesional. Begitu banyak dengan mudah dijumpai pada masyarakat orang-orang yang dapat memainkan piano, dan dengan bangga menyebut dirinya sebagai pianis. Namun banyak orang dan pianis tidak mengerti bahwa untuk menikmati, menjadikan sebagai hobi, apalagi menjadikan pianis sebagai profesi hidup memerlukan pengorbanan yang sangat tidak mudah.

Latihan menjadi "harga" yang harus dibayar untuk dapat mengerti, menikmati, memainkan musik piano dengan sempurna. Berlatih merupakan suatu kewajiban, yang berarti mau tidak mau, senang tidak senang, harus selalu dilakukan sampai akhir hayat agar keterampilan dan "rasa" bermusik dapat terus terjaga dengan baik. Ibarat tubuh yang selalu membutuhkan makanan dan minuman, dan ibarat iman Kristen yang harus selalu diperbaharui bahkan semakin dipertebal. 
Hal yang tidak asing lagi jika seorang pianis mengeluh: "saya tidak memiliki waktu yang cukup untuk berlatih karena terlalu banyak kegiatan lain di luar musik dan saya tidak dapat membagi waktu dengan baik; saya bosan dan jenuh dengan lagu ini; saya sudah melatih lagu ini berbulan-bulan tetapi sepertinya kemampuan saya tidak bertambah; saya sudah berlatih selama empat jam sehari tetapi jari dan tangan saya malah sakit semua; saya tidak tahu solusi yang harus dilakukan untuk melatih lagu ini; saya tidak mengerti program latihan apa yang harus dilakukan pada saat berlatih.”

Latihan bukanlah sekedar rutinitas duduk di kursi piano dan menghabiskan waktu dengan mengulang-ulang lagu saja. Latihan yang baik bukanlah hanya latihan yang membutuhkan banyak waktu, misalnya seorang pianis dapat dengan bangga berkata: "saya selalu latihan selama empat sampai delapan jam sehari.” Terlebih lagi latihan bukanlah memanjakan diri sendiri dengan asyik memainkan gaya-gaya musik yang menjadi selera diri sendiri. Tetapi latihan yang baik bagi seorang pianis adalah tentang bagaimana sang pianis dapat memanfaatkan seluruh waktu, semangat, kemampuan, pengetahuan secara optimal untuk meningkatkan keterampilan serta musikalitas.

\section{Latihan sebagai Rutinitas}

"Ingat ya, kamu harus rajin berlatih!" Itu kata yang selalu ibu Lira Gunawan sebagai guru piano penulis, kalimat yang sama juga terdengar dari guru piano kedua penulis yaitu Bapak Tan Khoen Tjiang, beliau berkata: "tidak ada yang instan dalam musik." Semua ungkapan yang memiliki inti yang sama, bahwa segala sesuatu yang berhubungan dengan musik tidak muncul begitu saja, semua memerlukan proses dan proses. "Sudah latihan apa belum hari ini?" Pertanyaan yang selalu penulis dengar setiap hari dari almarhum ayah saya Liem Sing Liang. Hal yang sama juga dijumpai jika seseorang ingin menjadi seorang pianis (sebutan seorang pemain piano), untuk menjadi seorang pianis tentu saja memerlukan proses yang panjang, latihan yang rutin dan memerlukan komitmen yang kuat.

Menilik pada sejarah seorang komponis Handel yang lahir di Halle, sebuah kota kecil di Jerman Tengah pada tanggal 23 Februari 1685. Ayahnya seorang ahli bedah, selain itu juga sebagai tukang cukur. Ayahnya sama sekali tidak punya minat terhadap musik, dan memaksa Handel berprofesi sebagai ahli hukum. Bakat musik Handel tidak bisa ditutuptutupi, dan meskipun mendapat tekanan dari ayahnya, ia nekat belajar musik secara sembunyi-sembunyi. Konon ia pernah memasukkan klavicord ke atas loteng rumahnya 
agar bisa bermain dan berlatih tanpa terdengar oleh ayahnya (McNeill, 2000). Demikian juga apa yang terjadi pada Ludwig van Beethoven, ambisi ayahnya (Johann van Beethoven) yang memiliki keinginan agar Beethoven memiliki ketenaran seperti Wolfgang Amadeus Mozart membuat Beethoven kecil mendapat disiplin latihan yang diluar batas dari sang ayah.

Bahkan di Eropa pada umumnya, tradisi menulis karya dalam bentuk partitur ditulis tanpa menyinggung kualitas para pemain, jadi jika pemain tersebut ingin memainkan karya tersebut harus melatihnya, dan jika kemampuannya tidak cukup untuk memainkan partitur tersebut, maka disarankan agar jangan memainkan karya tersebut, atau harus melatihnya terus menerus sampai karya tersebut mampu dikuasai (Mack, 2014).

Begitu pentingnya waktu latihan, mengakibatkan pianis harus benar-benar dapat memanfaatkan segala yang dimiliki dengan baik. Kadang keterbatasan pengetahuan menjadi kendala sehingga latihan tidak dapat maksimal, apalagi ditambah dengan sibuknya kegiatan menjadi masalah baru, keterbatasan waktu menjadi kendala tambahan, tak banyak pianis yang memiliki waktu terbatas dan tuntutan teknik lagu yang tinggi, membuat waktu tidak dapat dimanfaatkan dengan maksimal. Berikut saran agar dapat menggunakan waktu berlatih dengan sebaik mungkin.

\section{Berlatih dengan Sabar}

Berlatih dengan sabar yang dimaksud adalah berkaitan dengan tempo. Banyak sekali pianis yang salah berpikir. Kesalahan yang sering terjadi adalah menganggap bahwa berlatih dengan tempo yang cepat dapat lebih menyingkat waktu, bosan berlatih menggunakan tempo lambat dengan alasan lagunya tidak dapat dinikmati, ingin cepat lancar dan kemudian menganggap diri sendiri bagaikan pianis kelas dunia. Namun yang diterima bukanlah permainan yang baik dan rapi, tetapi kacau balau. Hal ini tidak akan menyingkat waktu, tapi justru akan menambah waktu.

Layaknya seorang bayi, sebelum ia bisa berlari, ia harus belajar merangkak, berdiri, berjalan, dan akhirnya dapat berlari. Proses berlatih piano juga harus dimulai dari tempo yang lambat. Bayangkan sesungguhnya banyak proses yang harus dilalui tubuh seperti mata dalam membaca partitur yang akan dimainkan, dimana mata harus melihat notasi, hitungan, tanda jari, pengkalimatan, dinamika, artikulasi, ataupun petunjuk yang lain dengan teliti. Apa yang dilihat oleh mata akan diterima otak, dan kemudian otak memerintahkan jari untuk menempatkan notasi, hitungan dan segala petunjuk yang ada 
seperti dinamika, artikulasi, tanda jari pada tuts piano. Kemudian telinga sebagai pengontrol, apakah yang dibunyikan sudah sesuai dengan segala petunjuk yang ada di dalam partitur.

Berlatih dengan tempo cepat atau terburu-buru ingin cepat bisa memainkan lagu akan membuat pianis tidak dapat membaca, memainkannya dengan teliti, bahayanya adalah apa yang terekam dalam ingatan pertama kali akan tertanam dan terus diingat, akibatnya menimbulkan kesalahan yang selalu diingat dan sulit untuk diperbaiki.

\section{Menggunakan Metronome}

Setelah notasi dapat dikuasai dengan baik menggunakan tempo lambat, tentukanlah tempo yang nyaman dengan menggunakan bantuan metronome, kemudian diulang berkalikali sambil menambahkan kecepatan pada metronome secara gradual. Hal ini sangat membantu dalam menjaga kestabilan tempo, kestabilan penempatan notasi, artikulasi dan tanda dinamka. Jika ada kesalahan tertentu pada salah satu birama, coba bereskan masalah itu terlebih dahulu. Intinya adalah jangan menambah kecepatan metronome jika masih ada masalah pada salah satu bagian birama.

\section{Mengetahui Teknik pada Lagu}

Setiap lagu pastilah memiliki teknik-teknik tersendiri yang perlu dianalisis, dilatih secara khusus dan dengan cara-cara tertentu. Salah satu buku etude piano yang terkenal yaitu HANON The Virtuoso Pianis (Hanon, 1928) memuat berbagai teknik dalam bermain piano dan memberi ulasan bagaimana trik untuk melatihnya, sehingga mendapatkan hasil maksimal. Demikianlah bila menghadapi suatu karya, harus dapat mengetahui teknikteknik yang digunakan dan melatihnya secara khusus. Ada seorang pianis remaja yang mengikuti suatu konser piano, setelah pentas selesai di belakang panggung ia berkata bahwa permainannya tidak "rata" dan tangannya merasa pegal, bahu tegang, otot jari seperti tertarik, padahal ia telah melatih lagu tersebut berbulan-bulan yang lalu, semua itu dikarenakan ia sendiri sebagi pianis maupun gurunya tidak mengetahui teknik-teknik apa yang digunakan dalam melatih karya tersebut, bagaimana menerapkan teknik tersebut dalam permainannya. Umumnya guru atau pianis terlalu sibuk dengan bermain bersih, tanpa salah dan melupakan teknik yang harus digunakan untuk mendukung permainannya, sehingga waktu yang telah digunakan selama berbulan-bulan menjadi percuma tanpa 
menghasilkan permainan yang baik, dan pianispun tidak dapat menikmati permainanya sendiri.

Terdapat banyak sekali teknik-teknik permainan piano yang perlu diketahui, berikut penulis menjelaskan beberapa teknik dalam bermain piano.

1. Latihan tangga nada, broken chord, arpeggio: layaknya manusia yang selalu memerlukan karbohidrat untuk beraktivitas, gunakanlah latihan ini menjadi kewajiban, biasanya dapat dipergunakan untuk pemanasan jari, sistem penjarian yang teratur pada tangga nada, broken chord dan arpeggio akan banyak sekali muncul pada karya-karya piano. Jika dapat menguasai sistem penjarian tangga nada, broken chord dan arpeggio akan sangat membantu dan mempermudah dalam latihan suatu karya.

2. Teknik pemberian nomor jari: dimana seseorang dituntut untuk dapat mengatur posisi jari pada not-not lagu tanpa menyulitkan pergerakan jari dan tetap menghasilkan suara seperti karakter lagu tersebut. Jika terdapat penomor jarian yang tidak sesuai dengan kebutuhan pianis pada partitur, maka sang pianis bisa mengubah tanda jari tersebut sesuai dengan permasalahan yang dihabapi. Hee Ah Lee seorang pianis dari korea yang hanya memiliki empat jari mampu membuktikan bahwa jika pianis dapat mengatur pergerakan jari dengan baik, pastilah pianis tersebut dapat memainkan suatu karya pada piano (Kurnia, 2008). Jika pianis yang hanya memiliki empat jari dapat memainkan Fantasie Impromtu karya F. Chopin tanpa kesulitan dalam pergerakan jari, terlebih bagi pianis yang memiliki jari yang normal (lima) tentunya dapat dimainkan pula.

3. Membaca secara cepat: cara ini sebenarnya harus sudah dibiasakan sejak pertama kali belajar piano, hal ini disarankan agar kebiasaan dapat terus terbentuk hingga tingkat yang lebih tinggi. Membaca cepat tidak memiliki kaitan dengan tempo. Membaca cepat adalah bagaimana mata dan pikiran dapat dengan cepat "mendeteksi" notasi, hitungan dan tanda-tanda dengan reaksi yang cepat. Biasakanlah untuk berekasi sebanyak mungkin dari notasi, hitungan, petunjuk yang ada dalam partitur. Berikut ini penulis memberikan contoh yang dapat dilihat pada gambar 1 dan 2 . 


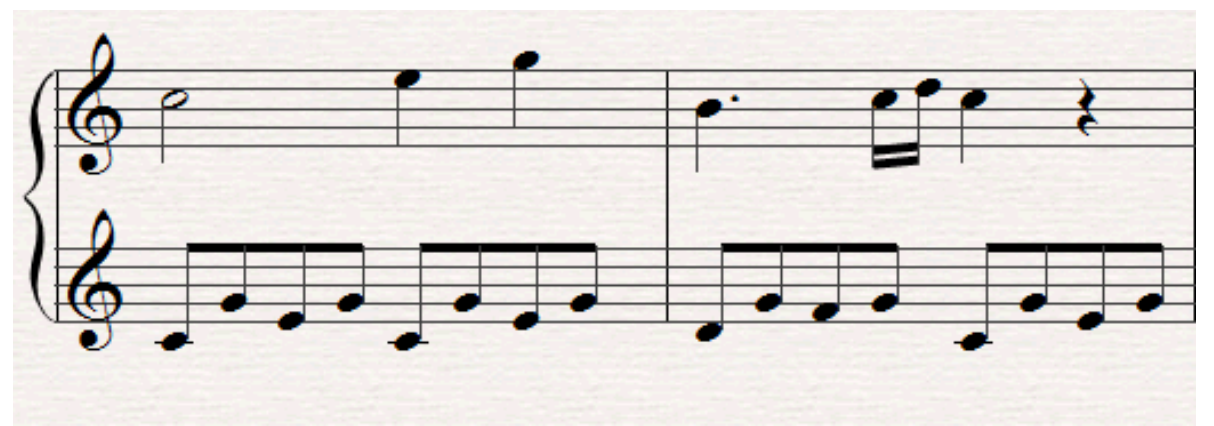

Gambar 1. Notasi Mozart Piano Sonata K. 545

(Andriyanto, 2018)

Melihat notasi pada gambar 1, maka bereaksilah secara grup, maksudnya hindari membaca satu persatu tetapi bacalah seperti sebuah kelompok akor. Dari contoh di atas dapat dibayangkan seperti membaca partitur pada gambar 2.

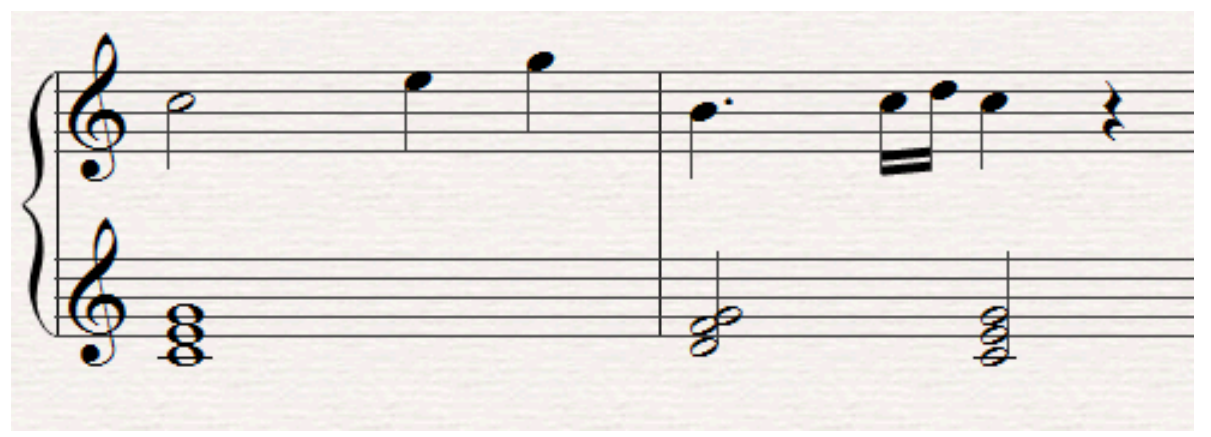

Gambar 2. Notasi yang dibaca secara Akor (Andriyanto, 2018)

4. Teknik pergelangan tangan: pergelangan tangan dapat bergerak seperti kepala yang dapat mengangguk, menoleh, maupun berputar, sehingga seseorang dituntut untuk dapat bermain se-rileks mungkin. Teknik ini dapat dilatih dengan cara menggunakan metronome dari tempo pelan ke tempo yang lebih cepat. Mendapatkan pergelangan tangan yang kuat dan rileks lebih diutamkan, bersabarlah hingga dapat menemukan gerakan yang sempurna, bayangkan pergelangan jari seperti sayap kumbang atau lebah, kecil ringan tetapi kuat dapat mengangkat seluruh tubuh binatang tersebut.

5. Teknik kerataan dan kecepatan: pada lagu-lagu tertentu terkadang menemukan not-not dengan nilai not yang sama berjajar begitu banyak dan menuntut kecepatan yang tinggi, bahkan terdapat pula yang menuntut kecepatan tinggi dan suara yang keras. Perlu diperhatikan untuk menempatkan jari selalu dekat dengan tuts merupakan kewajiban, jangan membuat jarak antara jari dengan tuts, karena jarak tersebut akan membutuhkan waktu dan tenaga sehingga mengganggu kecepatan. Tetapi sesungguhnya kemampuan 
jari masih dapat ditingkatkan lagi. Cara agar dapat meningkatkan kecepatan dan kekuatan otot jari dapat dilatih dengan menggunakan trik variasi ritme-ritme tertentu, tekanan berpindah dan staccato. Berikut penulis memberikan contoh notasi untuk latihan.

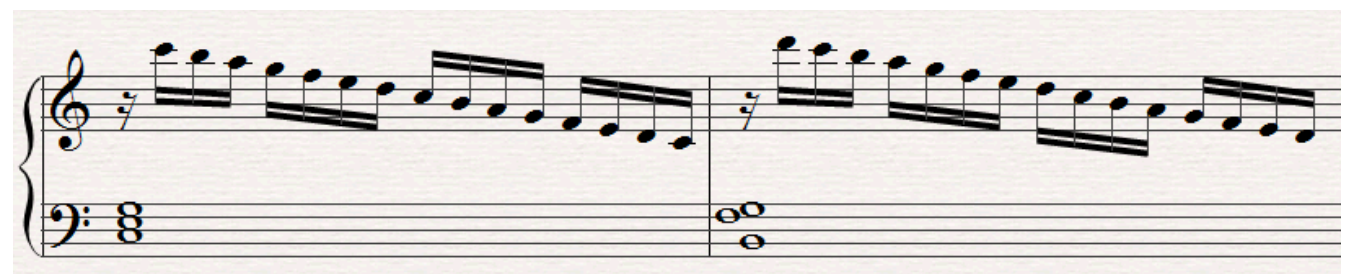

Gambar 3. Notasi Etude Czerny Op. 299 No. 1

(Andriyanto, 2018)

Notasi pada gambar 3 dapat dilatih dengan beberapa variasi irama, yang dapat berubah menjadi sebagai berikut.

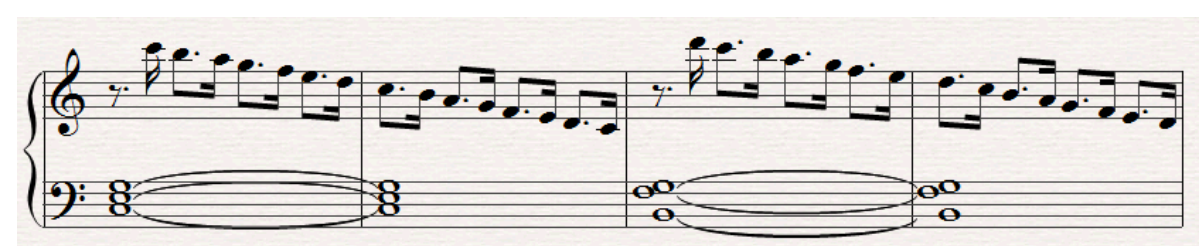

Gambar 4. Notasi Irama Satu

(Andriyanto, 2018)

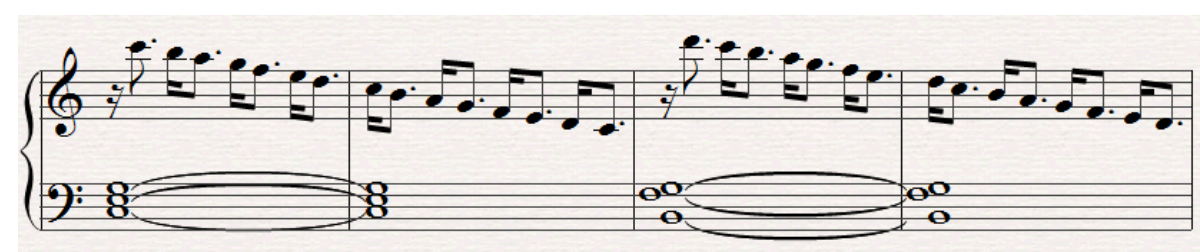

Gambar 5. Notasi Irama Dua

(Andriyanto, 2018)

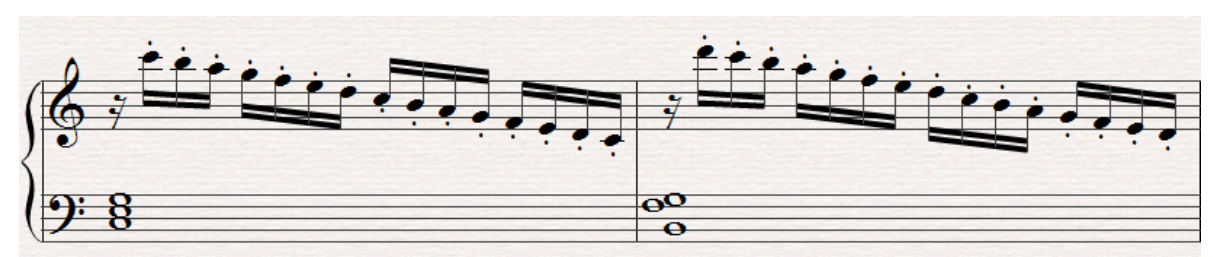

Gambar 6. Notasi menggunakan Staccato

(Andriyanto, 2018)

Selain irama yang sudah ditampilkan, masih banyak sekali variasi irama yang dapat diterapkan dalam latihan, baik untuk ritmik berpola genap maupun ganjil (5). Dengan 
tekanan atau aksen, khusus untuk trik ini dilakukan dengan cara memaksa jari menaikkannya tinggi-tinggi dan mendaratkannya dengan kuat. Berikut penulis memberikan contoh latihan tekanan dua berpindah pindah pada gambar 7 dan 8 .

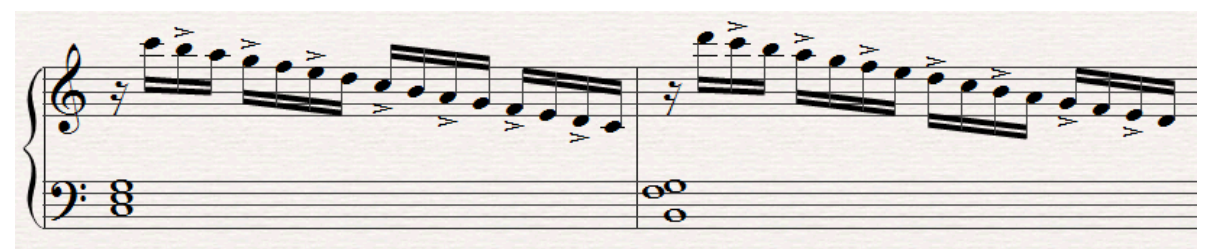

Gambar 7. Notasi pada Tekanan Pertama

(Andriyanto, 2018)

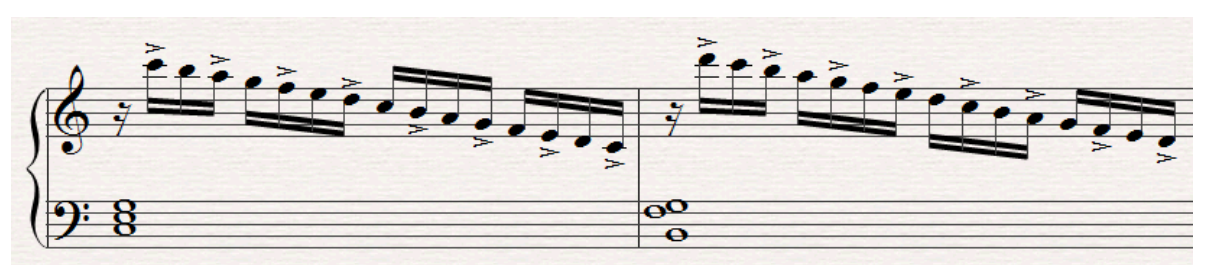

Gambar 8. Notasi Perpindahan Aksen pada Tekanan Kedua

(Andriyanto, 2018)

Selain tekanan dua berpindah, terdapat juga tekanan tiga dan empat. Selain contohcontoh di atas masih banyak lagi cara yang dapat digunakan, sesuai dengan kebutuhan lagu yang akan dilatih, bisa juga kita mengkombinasikan antara variasi ritme, staccato dan tekanan.

Berlatih dengan variasi ritme, tekanan dan staccato sesungguhnya akan memaksa jari-jari yang lemah secara pergerakan atau tekanan untuk bekerja lebih keras, sehingga otot jari akan semakin kuat dan seimbang sentuhannya. Melatih dengan trik ini juga sebenarnya meningkatkan musikalitas, dimana otak dan perasaan di ajak lebih berpikir kreatif dalam memperlakukan notasi, dan tentu saja menjadikan proses latihan lebih seru, sehingga latihan tidak membosankan.

6. Beda warna suara: pada karya piano terlebih lagi karya-karya zaman romantik-modern banyak dijumpai teknik dimana satu tangan memainkan dua suara atau bahkan tiga suara. Berikut penulis memberikan contoh pada gambar 9. 


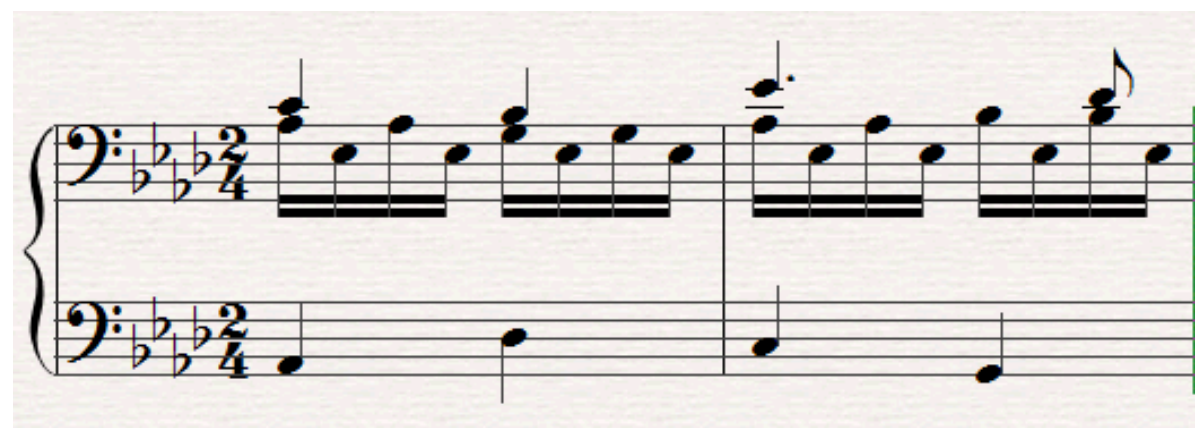

Gambar 9. Notasi Beethoven Sonata Pathetique $2^{\text {nd }}$ Mov (Andriyanto, 2018)

Dapat dilihat terdapat dua suara pada contoh gambar 9. Melodi (notasi yang menggunakan tangkai ke atas) serta harmoni berupa broken chord (yang menggunakan tangkai kebawah). Teknik seperti ini dapat dilatih menggunakan trik kombinasi legato dengan staccato, legato untuk melodi dan staccato untuk harmoninya. Perubahan notasi menggunakan kombinasi legato dan staccato dapat dilihat pada gambar 10.

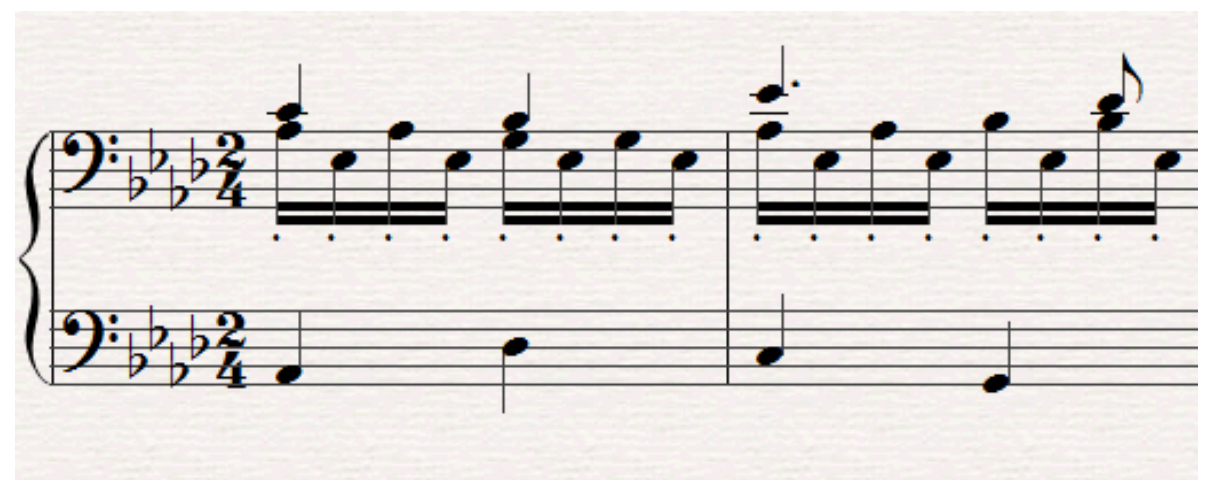

Gambar 10. Notasi Menggunakan Kombinasi Legato dan Staccato (Andriyanto, 2018)

Dengan melatih menggunakan kombinasi staccato dan legato, akan menghasilkan otak dan jari berpikir untuk melakukan dua tugas dalam satu kendali tangan. Hal ini membuat respon jari dan pikiran dapat menciptakan melodi yang lebih jelas dengan harmoni yang samar-samar.

7. Berlatih dengan variasi tempo: trik ini dapat dilakukan jika seluruh penguasaan notasi dan tanda-tanda sudah cukup. Latihan dengan trik ini dapat meningkatkan pengontrolan jari. Permainan yang sudah cukup dikuasai dengan baik dapat menyebabkan jari-jari secara otomatis bergerak, otomatis menekan, dan emosi tidak terkontrol karena segala sesuatunya berjalan secara otomatis. Hal ini dapat menyebabkan tidak rapinya permainan, warna suara yang dihasilkan juga sembarangan, seperti suatu mesin yang 
diprogram secara otomatis untuk mengerjakan suatu hal, maka jika terjadi suatu kesalahan atau keadaan yang tidak diinginkan mesin itu akan sulit dan bahkan tidak dapat dikendalikan. Pada intinya latihan dengan trik ini dipusatkan agar jari dan emosi tidak jalan sendiri, melainkan tetap pikiranlah yang menjadi pengendali. Berikut penulis memberikan contoh trik melatih dengan variasi tempo.

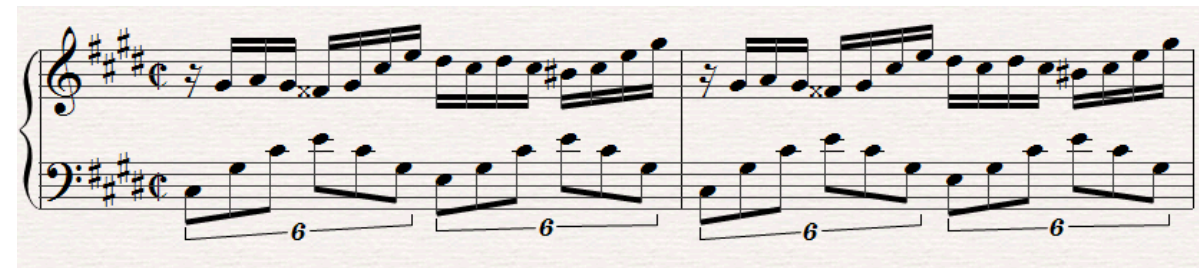

Gambar 11. Chopin Fantasie Improntu (Andriyanto, 2018)

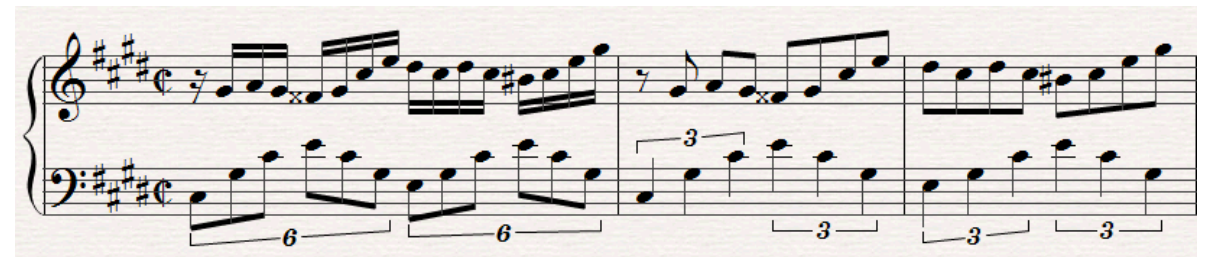

Gambar 12. Perubahan Notasi pada Gambar 11

(Andriyanto, 2018)

Birama ke 2 pada gambar 12, harga/ nilai notasi berubah menjadi dua kali lebih besar, sehingga menghasilkan tempo menjadi lambat. Variasi ini dapat juga dibalik menjadi seperti pada gambar 13 .

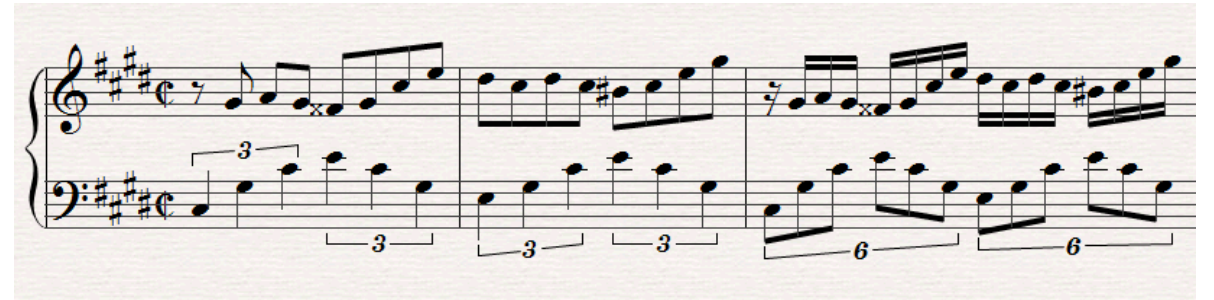

Gambar 13. Notasi Pembalikan Variasi pada Gambar 12 (Andriyanto, 2018)

Dengan tempo yang berubah-ubah dua kali lipat pada tiap birama, sehingga jari dan emosi akan tetap pada kendali otak. Perubahan tempo dapat juga dilakukan sesuka hati yang tidak harus terpaku pada birama. Melatih kembali dengan tempo sangat lambat juga dapat digunakan untuk melatih kesabaran memainkan suatu karya, juga dapat mengoreksi segala tanda yang tidak terlatih dengan baik. 
8. Bermain dengan mata tertutup: berlatih dengan cara ini juga hanya dapat dilakukan jika lagu sudah benar-benar hafal, atau bagian sulit yang membutuhkan lompatan jauh. Perlu diperhatikan dalam melakukan suatu lompatan, jari harus sedekat mungkin dengan tuts, jangan membuat pergerakan seperti membuat gunung. Pergerakan tersebut sangat tidak efisien karena menambah jarak dan membutuhkan kecepatan tambahan untuk mendarat pada notasi yang dituju. Berlatih dengan mata tertutup membuat reaksi terhadap lompatan tidak hanya bergantung terhadap mata, disisi lain insting akan dilatih untuk mengukur jarak lompatan tanpa bergantung dari penglihatan mata.

\section{Teknik Pedal}

Pedal merupakan alat yang sangat penting pada instrumen piano, dengan menggunakan pedal permainan dapat lebih "hidup". Sebelum pembahasan mengenai teknik pedal, sebaiknya mengetahui berbagai macam pedal dan fungsinya.

Penggunaan pedal kanan sebaiknya dilakukan jika penguasaan notasi sudah baik, hal ini dilakukan untuk mencegah jari bermalas-malasan dan tidak bergerak dengan legato. Hal tersebut disebabkan karena legato sudah tertutup oleh sustain. Demikin juga dengan kekuatan jari, jari cenderung akan melemah karena efek dari sustain. Pergantian atau pengangkatan pedal kanan sebaiknya memperhatikan suara bass, progresi akor pada partitur. Perhatikan juga efek suara, jika sudah terlalu keruh atau bercampur aduk sebaiknya diganti.

Pedal kiri atau damper pedal berfungsi untuk membuat efek suara lebih halus, pada upright piano, jika pedal kiri diinjak, maka hammer akan maju mendekat pada senar, sehingga membuat jarak antara hammer dan senar menjadi lebih dekat dan membuat pukulan hammer lebih lemah. Sedangkan pada grand piano, jika pedal kiri diinjak maka mekanik hammer akan bergerak ke kanan, dan membuat hammer hanya akan memukul satu senar saja, sehingga suara yang dihasilkan juga lebih halus, teknik ini biasanya disebut una corda.

Pedal tengah memiliki perbedaan antara grand piano dan upright piano. Pada grand piano berfungsi untuk menahan nada-nada tertentu saja jika diinjak, sedangkan pada upright berfungsi sebagai peredam, pedal ini juga disebut pedal latihan, karena berfungsi sebagai peredam, sehingga pianis dapat berlatih kapan pun tanpa mengganggu atau memberikan suara bising. Jika pedal ini digunakan maka aka nada selembar peredam yang 
akan turun diantara hammer dan senar, sehingga pukulan hammer pada senar akan terhalang oleh peredam dan suara yang dihasilkan sangat kecil.

Penggunaan pedal dapat divariasi dan tidak selalu diinjak penuh, misalnya dengan setengah pedal, seperempat pedal, atau gerakan seperti memompa. Ekperimen perlu dilakukan dalam menggunakan pedal, suara apa yang ingin dihasilkan: terang, merdu, seram, gelap, gemerincing (Genta, 2005).

\section{Mengetahui Latar Belakang Karya}

Setiap karya pastilah diciptakan oleh komponis. Setiap komponis pastilah berbeda, baik latar belakang, zaman (barok, klasik, romantik, dll), karakter kepribadian maupun tujuan lagu tersebut diciptakan, sehingga perlu diketahui untuk membantu kita mengapresiasikannya ke dalam bentuk suara. Memperlakukan karya-karya barok seperti karya Bach, Handel, jelas tidak bisa disamakan dengan zaman klasik seperti karya Mozart, Haydn. Karya barok mengutamakan tema yang rumit, teknik suara canon, sedangkan klasik mengutamakan kesederhanaan melodi, alberti bass menjadi ciri khasnya.

Menggunakan dinamika pada zaman barok dan klasik tentunya lebih terbatas jika dibandingkan dengan zaman romantik modern, hal ini disebabkan oleh karena piano pada masa itu memiliki perbedaan. Jika mempelajari karya pada zaman barok dan klasik, maka clavicord dan harpsichord yang digunakan, sedangkan mulai zaman Beethoven piano modern seperti sekaranglah yang dipergunakan. Mengenal berbagai karakter komposer juga perlu diperhatikan untuk meningkatkan kualitas permainan. Mendelssohn maupun Chopin merupakan komponis di zaman Romantik, namun Mendelssohn sangat berbeda dengan Chopin. Mendelssohn menaruh hormat terhadap komposisi klasik sehingga komposisi musiknya selalu berakar pada teknik-teknik klasik dibandingkan dengan Chopin yang lebih berani mengadakan modulasi, nada dasar yang jauh, dengan menggunakan akor-akor kromatik dan suara-suara tengah yang berjalan secara kromatik, sehingga menghasilkan gaya yang sensitif, melankolis, dan orisinil.

Memperlakukan tanda dinamika forte pada karya Mozart berbeda dengan Beethoven, karena secara kepribadian Mozart yang selalu ceria sedangkan Beethoven penuh dengan ekspresi. Berbeda lagi jika kita memainkan karya-karya milik Liszt, penuh dengan pergerakan aktraktif sehingga sangat tidak cocok jika dimainkan dengan gaya Brahms yang mengutamakan karakter harmoni yang kuat. Maka pergunakan waktu untuk 
membaca sejarah komponis penciptanya dan mencari ulasan-ulasan tentang lagu yang akan dimainkan.

\section{Berlatih adalah Mendengar}

Musik adalah seni yang berhubungan dengan suara, musik dapat dinikmati dengan mendengar, sehingga dengarkanlah permainan anda sendiri. Seberapa banyak waktu dan pengetahuan yang digunakan, serta variasi latihan yang dilakukan, akan menjadi sia-sia jika pianis tidak pernah mengoreksi permainannya sendiri. Untuk mengoreksi permainan diperlukan kepekaan telinga dalam mendengar hasil dari proses latihan, apakah efek suara yang diharapkan sudah terdengar dengan baik atau belum.

Di zaman modern ini, banyak cara agar dapat belajar seperti apa efek suara yang dihasilkan sebuah piano pada karya komposer, seseorang dapat menggunakan teknologi yang ada seperti rekaman suara atau video musik untuk belajar mengimajinasikan suara. Selain itu juga dapat menggunakan rekaman tersebut untuk mengoreksi permainan diri sendiri, apakah efek suara atau warna suara yang diharapkan sudah terdengar dengan baik atau belum.

\section{Kesimpulan}

Seorang pemusik tidaklah lepas dari proses berlatih, berlatih merupakan pekerjaan yang tidak mudah, membutuhkan ketekunan, cara-cara tertentu serta bukan hanya sesuka hati dalam berlatih. Jika berlatih dengan hanya asal berlatih saja, maka bukan hasil baik yang didapatkan melainkan rasa jenuh, frustasi dan bagi seorang pemusik hal ini sangatlah menghambat bagi perkembangan seorang pianis. Cara berlatih yang benar adalah jika seseorang dengan sabar mempergunakan seluruh kemampuan, pengetahuan, waktu yang dimiliki dengan seoptimal mungkin, untuk menyelidiki teknik-teknik yang digunakan dalam lagu tersebut, melatihnya dengan benar, memberikan latihan-latihan pendukung bila diperlukan. Berlatih juga bukan hanya duduk dan memainkan instrumen, tetapi dengan membaca dan mendengar, oleh sebab itu seseorang harus aktif mencari latar belakang dan mendengar lagu tersebut. 


\section{Kepustakaan}

Efendi Kurnia. (2008). Hee Ah Lee: The Four Fingered Pianist. Jakarta: Hikmah.

Genta. (2005). Lima buah Komposisi "Etude Jempol” untuk Piano. (Skripsi, Program studi Seni Musik Fakultas Seni Pertunjukan UKSW, 2005).

Hanon, C. L. (1928). The Virtuoso Pianist In Sixty Exercises For the Piano. New York: G. Schirmer, Inc.

Kodijat, Latifah-Marzoeki. (1969). Tangga Nada dan Tri Nada. Jakarta: Djambatan.

Kodijat, Latifah. (2002). Penuntun Mengajar Piano (revisi ketiga). Jakarta: Djambatan.

Mack, Dieter. (2014). Sejarah Musik (jilid 4). Yogyakarta: Pusat Musik Liturgi.

McNeill, Rhoderick J. (2000). Sejarah Musik 2. Jakarta: PT Bpk Gunung Mulia. 